\title{
Religious Differences in Electoral Turnout among Women in Northern Ireland
}

\author{
Bernadette C. Hayes \\ Institute of Conflict, Transition, and Peace Research \\ School of Social Science \\ University of Aberdeen \\ Aberdeen AB24 3QY \\ Scotland
}

Direct all correspondence to:

Bernadette C. Hayes

Institute of Conflict, Transition, and Peace Research

University of Aberdeen

Aberdeen AB24 3QY

Scotland

Phone: [01224] 273128

Email: b.hayes@abdn.ac.uk

Note: The 2015 Northern Ireland General Election Survey was collected by Jonathan Tonge, Jocelyn Evans, Bernadette C. Hayes, Paul Mitchell and Peter Shirlow and funded by the Economic and Social Research Council (Grant Number: ES/L007320/1). There is no conflict of interest. 


\title{
Religious Differences in Electoral Turnout among Women in Northern Ireland
}

\begin{abstract}
It is now commonly accepted that democratic elections with increased female participation and representation is an essential element of peacebuilding in postconflict societies. Yet, women are not a monolithic group and their needs are not homogeneous. This is especially the case in post-conflict societies marked by longstanding ethno-national antagonisms, where issues surrounding female unity and women's political participation are often considered secondary to resolving the national identity question. Using data from the 2015 Northern Ireland Election Survey, this paper examines female differences in electoral turnout between the two main religious groupings - Protestant and Catholic - in Northern Ireland. The results suggest the existence of a significant religious gap in electoral turnout among women, with Catholic women been significantly more likely to vote than Protestant women. A key factor in accounting for this phenomenon is differences in political engagement and levels of trust in political leaders.
\end{abstract}

Key words: Northern Ireland; religion; turnout; consociationalism; women; 


\section{Introduction}

Political participation and electoral turnout are considered the life blood of a healthy democracy. This is particularly the case in transitional societies where the participation of citizens in elections is viewed an indispensable tool not only for the confirmation of the new political order and its leaders but also for the development of democratic politics. As a number of commentators point out, not only are elections a major factor in the stabilisation and democratisation of emerging democracies and post-conflict societies but they have been increasingly included as a key aspect of negotiated peace agreements aimed at terminating civil wars (Lyons, 2005; Harbom et al., 2006; Hoddie and Hartzell, 2010). In fact, elections have been central to virtually every negotiated settlement since the end of the Cold war and are now considered an essential requirement for internationally supported post-conflict state-building (Bjornlund, 2004; Bjornlund et al., 2007; Kelley, 2012). Although both the timing and type of electoral system is open to some dispute, it has now generally accepted that the undertaking of fair and free elections - the 'bullets to ballots' approach - is vital for the transition to a democratic and peaceful society (Paris, 2004; Mansfield and Snyder, 2005; Reilly, 2008; Flores and Nooruddin, 2012).

Yet, what we know about the long-term consequences of elections for the advancement of democracy and political stability in emerging democracies and postconflict societies is both contradictory and somewhat limited. While some studies point to their democratic enhancing qualities (Linberg, 2006), particularly when combined with power-sharing and a negotiated peace settlement (Hoddie and Hartzell, 2005; Brancati and Synder, 2012), others highlight their conflict-regenerating properties, most notably in the immediate aftermath of war (Paris, 2004), while still others stress their long-term regressive tendencies, such as declining levels in turnout and the subsequent undermining of democracy (Fornos et al., 2004; Kostadinova and Power, 2007; O'Donnell and Schmitter, 2013). Moreover, in the vast majority of cases, it is the influence of institutional factors - such as the electoral system - at the aggregate level which has been the focus of attention. By contrast, individual characteristics of ordinary citizens have rarely been investigated. This is particularly the case when the influence of gender is considered. Furthermore, the few studies that do exist tend to focus on the gender gap in electoral participation rather than 
differences between women (Inglehart and Norris, 2003; Coffe and Bolzendahl, 2011).

The absence of such research may be considered surprising for the following reasons. First, it is now increasingly recognised that the political contribution of women is vital for the successful and peaceful transition of societies emerging from conflict. A view that has been repeatedly endorsed by the United Nations Security Council in a series of resolutions on Women and Peace and Security advocating women's full and equal participation in both the prevention and resolution of conflicts as well as in all areas of peacebuilding, including electoral processes and constitutional reform. ${ }^{1}$ Second, it is important to note, however, as proponents of intersectionality suggest, ${ }^{2}$ women do not form a politically monolithic group. As a number of studies have shown, not only are women divided by a range of factors such as class, race, age, and religion - in terms of their electoral turnout and party preferences in established Western democracies (Campbell, 2012; Huddy et al., 2008; Carroll, 2014; MacManus, 2014) but this is also the case in many post-conflict societies where women are often sharply differentiated both by long-standing ethnic loyalties as well as unequal access to resources (Waylen, 2007; Baur, 2009; Hassenstab and Ramet, 2015). Not all political analysts, however, endorse this view, most notably when post-conflict societies in Africa are considered. As a number of scholars have noted, not only have many post-conflict African countries, particularly since the 1990s, seen major advancements in women's political representation but there is also evidence to suggest that these female representatives have sought alliances that cut across ethnic, religious and class differences to ensure the successful passage of legislative reforms concerning the rights of women (Arostegui, 2013; Tripp, 2015).

It is with these considerations in mind that this study focuses on differences in electoral turnout among women in Northern Ireland. The article proceeds in two stages. First it focuses on the political participation of women in Northern Ireland, particularly in the post-accord period. Building on this analytical discussion and using nationally representative data from the 2015 Northern Ireland General Election Survey, ${ }^{3}$ it examines differences between the two main religious groupings - Catholic and Protestant - in electoral turnout among women. Religious differences rather than 
differences in communal affiliation - nationalist versus unionist - were chosen as the primary distinguishing variable of interest because of the relatively large number of women - 38.2 per cent in this instance - who were unwilling to endorse a nationalist or a unionist label, the majority of whom belonged to the Protestant tradition. ${ }^{4}$ More importantly, however, and as in previous elections, religious background remained the primary determinant of voting during the 2015 Northern Ireland Westminster election (Tonge and Evans, 2015). Moreover, in this instance, its influence was further reinforced by the introduction of unionist electoral pacts in four constituencies where, contrary to expectations, turnout actually increased by an average of 3.5 per cent. ${ }^{5}$ As Tonge and Evans (2015:131) put it: 'The election amply demonstrated how the linkage between religious community background and voting patterns remain the strongest in Europe.'

The use of Northern Ireland as a case study may be considered particularly appropriate for the following three reasons. First, the Northern Ireland peace accord, based on consociational power-sharing, is now considered an exemplar of conflict management throughout the world. Second, at least as far as these consociational power-sharing forms of governance are concerned, there is evidence to suggest that women are often ill-served by such arrangements, where gender equality and the political rights of women is often sacrificed in the interests of resolving communal identity (Byrne and McCulloch, 2012). Finally, unlike previous studies which have focused on gender and peace settlements in countries transitioning to democracy, Northern Ireland offers a unique opportunity to investigate not only differences in electoral turnout among women but also in a society where they have been deeply divided by protracted ethno-national conflict.

\section{Women, Political Participation and the Northern Ireland Agreement}

Signed in April 1998, the Northern Ireland Agreement sought to bring to an end almost 30 years of violent conflict. Based on a consociational model of conflict regulation and the principle of 'parity in esteem', a key assumption of the Agreement was that long-standing and entrenched communal divisions could be accommodated and eventually ameliorated through institutional power-sharing arrangements. These power-sharing arrangements included the formation of a Northern Ireland Assembly with a power-sharing Executive, plus the introduction of a cross-community support 
principle for any major decisions taken by the Assembly (Hayes and McAllister, 2013).

Although the Agreement was primarily designed as a mechanism to manage, and eventually alleviate ethnonational conflict, it was also the first political initiative to formally recognise women's right to political inclusion, and committed the various parties to ensuring the 'right of women to full and equal participation in political life.' While this obligation concerning women's political inclusion was not endorsed in the later St Andrews (2006) and Hillsborough (2010) agreements, ${ }^{6}$ in both the subsequent Stormont House (2015) and A Fresh Start: The Stormont Agreement and Implementation Plan (2015) agreements, the parties again pledged their commitment to the 'advancement of women in public life.' Finally, unlike other peace agreements where women are seldom at the negotiating table, ${ }^{7}$ the 1998 Northern Ireland Agreement did include the formal participation of women via the Northern Ireland Women's Coalition (NIWC), ${ }^{8}$ although the final negotiations were exclusively male (Hayes and McAllister, 2012). In fact, the inclusion of the formal recognition of the political rights of women in the final draft of the Agreement was both initiated and secured by the NIWC (Fearon, 1999).

Despite these obligations and commitments, the post-Agreement period has not proved conducive for the advancement of women. As a number of scholars point out, not only have women been disproportionately negatively affected by the previously highly 'militarised nature' of Northern Ireland, such as the rise in domestic violence and the lack of reproductive rights, but the political arena in particular has remained a 'cold house' for women (Jarman, 2004; Galligan, 2013; Horgan and O'Connor, 2014). Although female political representation has increased somewhat since 1998, it still remains low in comparison to Scotland and Wales ${ }^{9}$ and, with the exception of the Italian regional legislatures, it is still the lowest in Western Europe for comparable devolved institutions (Potter, 2013). Even the establishment and subsequent electoral success of the NIWC in both the 1996 Northern Ireland Forum and 1998 Northern Ireland Assembly elections was a very short-lived endeavour. Undermined by the consociational power-sharing arrangement and deserted by an increasingly polarised electorate - that returned both the Democratic Unionist Party (DUP) and Sinn Fein as their primary ethnic party of choice - both representatives 
failed to be re-elected in the 2003 Northern Ireland Assembly elections and the party was formally disbanded in 2006 (Braniff and Whiting, 2015).

There is also evidence to suggest that some of the main political parties have demonstrated a widespread lack of interest in promoting female participation and representation in politics (Matthews, 2014). Despite the progress made by some of the political parties, most notably the efforts of Sinn Fein to promote women into leadership roles, the political environment remains heavily male dominated and this is particularly the case when the gender composition of the unionist parties within the Northern Ireland Assembly is considered. Moreover, even with their electoral gains in the 2016 elections, women constitute only 21 per cent of the 38 Members of the Legislative Assembly (MLAs) within the DUP - the largest party in the Assembly and the main unionist party - while the equivalent proportion among Sinn Fein - the second largest and main nationalist party in the Assembly with 28 MLAs - is markedly highly at 36 per cent. Moreover, unlike Sinn Fein which supports quotas to increase the number of female candidates, particularly in winnable seats, the DUP remains firmly opposed to such a policy. ${ }^{10}$ This view it should be noted is also held by the newly elected female leader of the DUP, Arlene Foster. ${ }^{11}$ Although there is some evidence to suggest greater support for increasing female political representation among more recent members, positive discrimination and quotas remains deeply opposed by most party members and elected representatives (Braniff and Whiting, 2015).

In summary, despite its promise of a new beginning, the post-Agreement period has proved to be an inhospitable place for women and this is particularly the case when the political arena is considered. In comparison to their male counterparts, political apathy among women remains widespread as does their greater lack of support for the new political arrangements and accompanying lower levels of trust in their political leaders (Gormley-Heenan and Devine, 2010; Hayes and McAllister, 2012). Moreover, there is some evidence to suggest that political disillusionment is more prevalent among women from within the unionist tradition, particularly when attitudes towards devolved government are considered, where female political representation continues to lag significantly behind that of their nationalist counterparts (Hayes and McAllister, 2012). As a number of commentators have noted, 
although ethnic identity remains the dominant cleavage within this society, nationalist parties, for the most part, have a far better track-record in promoting gender policies, particularly the political representation of women, than that of their unionist counterparts (Matthews, 2014; Baniff and Whiting, 2015).

\section{Women and Electoral Turnout}

A cornerstone of the 1998 Northern Ireland Agreement was the enhanced political participation of women. However, as noted earlier, much of the post-Agreement period has been characterised by an increase in female apathy and a lack of political representation and support for its political institutions. To what extent is this also the case when electoral participation is considered? Furthermore, are there any notable differences between women in relation to this issue?

Table 1 addresses this question using the 2015 Northern Ireland Election Survey. The results are clear. Although a clear majority of the female electorate - or 62 per cent, in this instance - turned out to vote, as a group, it is Catholic women who are notably more likely to do so than Protestant women. More specifically, whereas 70 per cent of Catholic women claimed to have voted in the 2015 Westminster election, the equivalent figure among Protestant women was markedly lower at just 55 per cent, or a religious gap of 15 percentage points.

\section{[Insert Table 1 about here]}

Moreover, there is evidence to suggest that this religious gap in greater electoral turnout among Catholic women is a relatively recent phenomenon which dates from 1998 onwards. As the data in Table 2 demonstrates, whereas electoral turnout was higher among Protestant women than Catholic women - 82 per cent as compared to 75 per cent - during the 1992 election, by 1998, the pattern had reversed. In 1998, 78 per cent of Protestant women as compared to 86 per cent of Catholic women claimed to have voted in the Northern Ireland Assembly election. While this gap in electoral turnout in favour of Catholic women remained relatively stable over the following decade - hovering around 8 percentage points - by 2015 , it had almost doubled to 15 per cent. 
It is important to note, however, that this religious gap in turnout among women is not only greater than the religious gap among men but also than the gap in turnout between the two religious communities as a whole. As the data in Table 2 also demonstrates, whereas Catholic men were notably less likely to vote than Protestant men both prior to and in the immediate post-Agreement period, by 2011, electoral turnout rates among Catholic men outstripped those of their Protestant equivalents by a margin of 12 per cent. ${ }^{12}$ Although the gap has narrowed considerably since then 73 per cent as compared to 70 per cent during the most recent 2015 Westminster election - Catholic men are still somewhat more likely to turn out to vote than Protestant men. Finally, when differences between the two religious communities are investigated, there is again evidence to suggest that since 1998, electoral turnout has become an increasingly Catholic phenomenon. As the data in Table 2 also shows while Protestants were more likely to vote than Catholics in the pre-Agreement period they were somewhat less likely to do so at the turn of the century; 74 per cent of Protestants as compared to 77 per cent of Catholics claimed to have voted in the 2003 Assembly elections. Since then levels of electoral participation have eroded significantly among Protestants. In 2015, while 72 per cent of Catholics claimed to have cast their vote, the equivalent figure among Protestants was just 62 per cent, or a religious gap of 10 percentage points. ${ }^{13}$

In summary, the results are clear. While traditionally electoral turnout was higher among Protestants than Catholics, it is now Catholics, and not Protestants, who are more likely to turn out to vote. It is important to note, however, that this lack of electoral participation among Protestants has become a predominantly female phenomenon. At just 55 per cent in the most recent Northern Ireland Westminster election, currently not only are turnout rates among women in the Protestant community significantly lower than those within either the male or female Catholic population - 70 per cent and 73 per cent, respectively - as well as those among the Catholic population as a whole (72 per cent), but also as compared to those of Protestant men (70 per cent).

\section{Explaining Religious Differences in Female Electoral Turnout}


There are several possible explanations as to why Protestant women are less likely to vote than Catholic women, the most obvious being there differing levels of support for devolved government. As noted earlier, it is this factor - a greater lack of support for the Northern Ireland Assembly and particularly for its power-sharing executive which not only accounts for the gender gap in levels of support for devolution within both religious communities but also for the greater lack of support among Protestant women as compared to their female Catholic counterparts (Hayes and McAllister, 2012). The results in Table 3 lend some further support to these findings. As a group, it is Protestant women who stand out as the least positive or, in this instance, the most indifferent in their views and this is particularly the case when attitudes towards power-sharing arrangements are considered. For example, whereas 68 per cent of Protestant women as compared to 70 per cent of Catholic women supported the Assembly/Executive, the equivalent figures among those who adopted an indifferent position - neither supported or opposed - was 28 per cent and 23 per cent respectively. An even more pronounced pattern emerges when attitudes towards power-sharing are considered. While only 59 per cent of Protestant women as compared to 77 per cent of Catholic women endorsed power-sharing, over a third of Protestants and just under a fifth of Catholics within the female population expressed indifference in terms of their views. ${ }^{14}$

\section{[Insert Table 3 about here]}

There is also evidence to suggest that this religious gap in level of female support has decreased overtime. This pattern holds regardless of whether support for the Assembly/Executive or attitudes towards power-sharing are considered. As the data in Table 4 demonstrates, while levels of support for the Northern Ireland Assembly/Executive among the female Protestant and Catholic population were 80 per cent and 87 per cent, respectively in 1998, or a gap of 7 percentage points in favour of Catholic women, by 2015, the equivalent figures were 68 per cent and 70 per cent, or a gap of just two percentage points. An even more pronounced pattern is echoed when attitudes towards power-sharing are examined. In 1998, while 86 per cent of Catholic women as compared to just 59 per cent of Protestant women supported such arrangements, or a gap of 27 percentage points, the equivalent figures in 2015 were 77 and 59 per cent, respectively, or a gap of 18 percentage points. This 
is not to discount, however, the notable decline in the level of support for powersharing among Catholic women.

\section{[Insert Table 4 about here]}

A second possible explanation for the lack of Protestant female electoral engagement is their greater lack of party attachment and trust in political leaders. However, previous research in relation to this issue is somewhat contradictory and mixed. While some studies find no notable differences among women in relation to both these issues (Gormley-Heenan and Devine, 2010), others suggest a differential effect with greater levels of political engagement among Catholic women but comparatively higher levels of trust in their political leaders among women within the Protestant community (Hayes and McAllister, 2012).

The results in Table 5 lend some partial support to these previous findings, with Protestant women being the least politically engaged in their views. While just two-fifths of Protestant women claimed to have a party identification, 46 per cent of Catholic shared this view. ${ }^{15}$ It is important to note, however, there is evidence to suggest that this greater party attachment among Catholic women is a relatively recent phenomenon, which dates from the turn of the century. Previous Northern Ireland election survey data indicates that whereas 46 per cent of Protestant women as compared to 42 per cent of Catholic women claimed a party attachment in 1998, by 2001, 43 per cent of Protestant women as compared to 48 per cent of Catholic women reported such a view.

\section{[Insert Table 5]}

A similar, albeit more pronounced, pattern emerges when trust in political leaders is considered, with Protestant women being the least trusting in their views. Whereas just under half of Protestant women claimed to have some trust in both political leaders - Peter Robinson and Martin McGuiness - the equivalent percentage among Catholic women was 15 percentage points higher at 64 per cent. There were also major religious differences in views in relation to this issue with, as expected, each leader being held in a much more positive light by members of their own community than the opposing one. This is not to deny, however, the much higher levels of support among Catholic women for Martin McGuinness as compared to that 
for Peter Robinson among women within the Protestant community. While less than half of all Protestant women claimed to have some trust in Peter Robinson, the equivalent proportion among Catholic women in relation to Martin McGuinness was significantly higher at 63 per cent. Moreover, while a notable minority of Catholic women, or around a fifth in this instance, were willing to place their trust in Peter Robinson, levels of trust among Protestant women are an almost exclusively Peter Robinson phenomenon. ${ }^{16}$

It is important to note, however, that this female differential in trust between the two political leaders is a relatively recent phenomenon dating from the previous election. As the data in Table 6 demonstrates, while levels of trust in both political leaders among Catholic women has risen considerably - from 39 per cent to 64 per cent - since the last Westminster election in 2010, they have declined - from 56 to 49 per cent - among women in the Protestant community. These patterns are replicated when levels of trust towards the two political leaders are considered separately. Although trust ratings for Peter Robinson and especially Martin McGuinness rose sharply among women within the Catholic community, they experienced a consistent, albeit moderate, decline among Protestant women. The growing lack of trust particularly in Peter Robinson among Protestant women is, perhaps, not an unexpected finding, given the various political scandals - allegations of financial corruption and his wife's affair with a teenager - which led to his temporary resignation as First Minister in January 2010 and, according to some political pundits, the surprising loss of his Westminster seat in May 2010 (McKittrick, 2010). ${ }^{17}$

[Table 6 about here]

\section{The Religious Gap in Female Electoral Turnout: Assessing the Explanations}

There are, then, two possible explanations that could account for the greater electoral participation of Catholic women, each of which demonstrates a degree of empirical support at least at the bivariate level: attitudes towards devolution/system of governance and levels of political engagement/trust in leaders. In each case, Catholic women are more supportive and engaged than Protestant women. To what extent do these two explanations account for female differences in electoral turnout once a wide range of other factors are taken into account? Table 7 addresses this question. To 
assess the two explanations, four logistic regression models are estimated: Model 1 which shows the effect of religion on female electoral turnout; Model 2 which shows the estimate for religion, controlling for socio-economic background and national identity; Models 3 and 4 which show the religion effect when the influence of our two explanations - support for devolution/systems of governance and party attachment/trust in its political leaders - are also taken into account. The figures in each model are the parameter estimates, while the standard errors for each of the estimations are shown in parentheses. Finally, the 'odds ratio' statistics shows whether the impact of both the control and explanatory variables increases (score greater than 1) or decreases (score less than 1) the likelihood of electoral turnout in this instance.

\section{[Insert Table 7 about here]}

The results lends some partial support to our hypothesis concerning the impact of both factors - attitudes towards political institutions and party support/trust in political leaders - on religious differences in female electoral turnout. As the data in Table 7 demonstrates, although religion has an independent and statistically significant effect on electoral turnout, an effect that remains when a range of socioeconomic control variables and national identity (Model 2) as well as attitudes towards the political institutions (Model 3) are included in the logistic regression analysis, these statistically significant differences no longer hold when party support and attitudes towards political leaders are also added to the investigation. ${ }^{18}$

Focusing initially on Model 1, the results are clear. Religion demonstrates a statically significantly effect on electoral turnout. More specifically, Catholic women are almost twice as likely as Protestant women - the odds ratio is 1.94 - to turn out to vote. An almost identical result emerges when a range of socio-economic control variables and national identity are included in the logistic regression analysis (see Model 2). Religion is again a significant predictor of electoral turnout with Catholic women being, in this instance, over twice as likely as Protestant women - the odds ratio is 2.20 - to turn out to vote, net of all other factors. This is not to suggest that religion is the only significant determinant of electoral behaviour in this instance. Other notable determinants include the positive effects of church attendance, age, and having a tertiary education. Regular church attenders, older individuals and the well- 
educated are significantly more likely to turn out to vote than irregular attenders, the young, and the lesser-educated.

A similar pattern emerges when the influence of attitudes towards political institutions - - support for devolution/systems of governance - are also included in the analysis (see Model 3). Religion is again a statistically significant predictor of electoral turnout. More specifically, Catholic women are again over twice as likely as Protestant women - the odds ratio is 2.35 - to turn out to vote, net of all other factors. As in our earlier analysis, other notable predictors include the positive effects of age and completing a tertiary education, as well as holding a positive view of the Assembly/Executive. In fact, women who endorsed the Assembly/Executive were almost twenty more times likely net of all other factors to turn out to vote than those who did not.

Finally, when the influence of both party support and trust in political leaders is added to the analysis, religion is not a significant predictor of electoral turnout (see Model 4). Rather the key net predictors of electoral turnout in this instance are both partisanship and trust in political leaders. Whereas women who had a party attachment were almost eight times more likely - the odds ratios is 7.54 - to turn out to vote than those who did not, women who claimed to have trust in the two main political leaders - Peter Robinson and Martin McGuinness - were nearly four times more likely to do so than those who did not. This is not to discount, however, the continuing independent and positive net effect of support for the Assembly. However, at least as far as religious differences in female electoral participation in Northern Ireland is concerned, the results suggest that it is the addition of these two factors - party attachment and trust in political leaders - which explains the religion gap in voting behaviour among women. Once these two factors are included in the analysis, religion is no longer a significant net predictor of electoral participation among women. In other words and in comparison to their female Catholic counterparts, it is their greater political disengagement, both in terms of their party attachment and their trust in political leaders, which accounts for the significantly lower electoral participation rates among Protestant women in this instance. 


\section{Conclusion}

Over the last few decades, the role of elections and electoral turnout in emerging democracies and post-conflict societies has received increasing research attention. In fact, the holding of elections and the electoral participation of its citizens is now considered a key factor in ensuring the stability and legitimacy of the new political arrangement. Yet, what we know about the long-terms consequences of electoral participation for post-conflict societies remain both limited and contradictory, especially when differences among women are considered. Despite increasing recognition as to the importance of the political contribution of women for the successful transition of societies emerging from conflict, the electoral mobilisation of citizens along ethnic and/or religious lines and the calculation of the 'ethnic/religious headcount' has dominated the political agenda. This is particularly the case when consociational forms of power-sharing arrangements are considered, where women's electoral participation and support for these new political arrangements is considered of secondary significance at best if not totally irrelevant. As McGarry and O'Leary (2009: 82) put it: 'As for the suggestion that consociational politics promotes a superficial ethno-national politics at the expense of more popular questions of class or gender, we submit that there is no evidence, either from public opinion or from elections, that the latter questions are more popular... Elections in Northern Ireland are free and fair, and turnouts are reasonably high when compared to other democratic jurisdictions, so the lack of support for class-based or gender-based parties cannot be explained by undemocratic structural impediments or by the presence of a large section of the electorate that does not vote.'

The results of this investigation calls into question this assertion and points to the need to include gender as an additional key component in consociational powersharing arrangements. First, our results confirm the existence of a significant religious gap in women's electoral participation. Protestant women are notably less like to turn out to vote than Catholic women. Second, these religious differences in turnout among women are not a recent phenomenon or just a by-product of one particular election - the 2015 Westminster election - but date from 1998 onwards, and coincide with the first assembly elections based on the consociational powersharing arrangements. Third, this religious gap in turnout among women is not only 
greater than the religious gap among men but also than the gap in turnout between the two religious communities as a whole. Fourth, while only future research can determine the extent to which this female gap in turnout between the two communities continues for the foreseeable future, particularly in the light of diminishing turnout among the nationalist community and the increasing political representation of unionist women, the notable size of the gap suggests that it will remain for some time to come. Thus, contrary to the gender-blind assertions of consociational theorists, mechanisms to deal with the democratic deficit among Protestant women, or their much higher rates of abstention, must now lie at the very heart of Northern Ireland's politics, including its consociational power-sharing arrangements.

Our results also confirm the importance of two key factors in consociational power-sharing arrangements - party attachment and trust in their political leaders - in accounting for the religious gap in turnout among women. More so than any other issue, it was the greater antipathy among Protestant women towards the primary political agents involved in the electoral process - political parties and their leaders which accounted for their higher rates of abstention. Again, there is evidence to suggest that this antipathy among Protestant women in terms of their political attachments is a relatively recent phenomenon dating from the turn of the century. What may account for these findings? One explanation is the differing responses of the parties and their leaders to the political role of women. As noted earlier, although ethnic divisions eclipse all other cleavages within this society, nationalist parties have been much more proactive in promoting gender policies, particularly the political representation of women, than that of their unionist counterparts. Moreover, there is evidence to suggest that this lack of female political representation is it odds with the preferences of the female Protestant population at large (Baniff and Whiting, 2015).

This is not to deny, however, the potential ability of consociational powersharing arrangements to accommodate female political participation and gender equality more generally. As Byrne and McCullock (2012: 566) point out: 'there is nothing inherent in power-sharing that cannot be made more democratic and inclusive of women.' However, the willingness and ability of political parties and their leaders to address this female representation issue and mobilise the electorate around such cross-cutting allegiances, including gender equality, will not be an easy task (Kennedy 
et al., 2016). Given the current dominance of ethno-nationalism as the singular mark of division within the formal political structures and the use of the ballot box as the sole measure of political legitimacy, both a major revision of the underlying political arrangements and the introduction of mechanisms to actively promote the inclusion and participation of women are needed. However, as Byrne and McCullough (2012) also point out, such revisions and mechanisms to both accommodate and increase female political representation and participation will not be enough. As a number of commentators have also noted, what is further required is much greater attention to the gendered nature of the conflict, including the reproduction of patriarchal privilege in consociational post-conflict political institutions and their power-sharing practices (Galligan, 2006, 2013; Byrne and McCullock, 2013; Kennedy et al., 2016).

These results have a number of implications for other societies emerging from deep-seated ethnic and/or religious conflict. First, post-conflict scholars must address the relationship between conflict and gender. Despite the claims of consociational scholars, the impact of such power-sharing agreements is not a genderneutral activity. Second, greater consideration should be paid to the differential experience of women in post-conflict societies. As a number of scholars point out, women are not a homogeneous group. This is particularly so in post-conflict societies, where women remain deeply divided by differing ethnic allegiances. Finally, the results point to the crucial role of both political parties and their leaders in determining female political participation in the post-accord period. While much attention has been paid to the role of political parties in strengthening or moderating ethnic identities and tribalism among voters via such consociational power-sharing arrangements, their role in perpetuating gender inequality and enhancing divisions among women, by contrast, is much neglected. As the scholarship on intersectionality illustrates, ethnically-divided parties may not only undermine the political participation of women, but by putting ethnicity and gender in conflict, they can create a culture of division which subverts not only gender equality but also the political rights of all women. 


\section{Endnotes}

To date, the United Nations Security Council has passed eight resolutions under the international women, peace and security agenda - 1325 (2000); 1820 (2008); 1888 (2009); 1889 (2009); 1960 (2010); 2106 (2013); 2122 (2013); 2242 (2015) - in relation to this issue. And, while the UK government has been at the forefront in promoting their implementation via the establishment of a National Action Plan (NAP), to date the experiences of women in Northern Ireland have been excluded from such plans as it does not consider the previous violence in Northern Ireland to be that of an 'armed conflict.' Moreover, although some progress has been made in relation to this issue, namely via the establishment of an All Party Group on UNSCR 1325 in the Northern Ireland Assembly in December 2010, attendance rates have been desultory and it lacks any statutory powers (Hoewer, 2013).

2 Originally proposed by Black and other ethnic minority feminist scholars in the United States, in its most elementary form, intersectionality contends that the distinguishing categories within a society, such as gender, religion, race/ethnicity, age, sexual orientation, class, and other markers of identity and difference, do not function independently but, rather, act in tandem as interlocking or intersectional phenomena. Thus, a key focus of this approach is to investigate the intertwined nature of these identities both as a source of oppression as well as privilege (see Manuel, 2006). In fact, politicians have long been aware of this issue, namely the significant political diversity among groups of women by race, religion, generation and class, and have specifically designed electoral campaign strategies - such as the targeting of 'mumsnet' vote (middle income mothers) in the 2010 UK general election - on the basis of these differences.

The 2015 Northern Ireland Election Survey was a nationally representative postelection survey of all adults aged 18 years or older conducted immediately after the May 2015 general election. Using face-to-face interviews and with a response rate of $68.3 \%$, the survey was carried out by Social Market Research and based on a random sample of 1,810 adults. The 2015 Northern Ireland General Election Survey was collected by Jonathan Tonge, Jocelyn Evans, Bernadette C. Hayes, Paul Mitchell and Peter Shirlow and funded by the Economic and Social Research Council. Moreover, when the relationship between religious identity, communal affiliation and electoral turnout was considered, it was Catholic women, albeit 
among those who were willing to adopt a nationalist label, who were the most likely to cast their vote. For example, whereas 78.2 per cent of CatholicNationalist women claimed to have turned out to vote, the equivalent figures among Protestant-Unionist women, and Catholic and Protestant women who were unwilling to adopt their respective communal affiliation were 72.8 per cent, 53.3 per cent and 23.4 per cent, respectively.

5 While the Democratic Unionist Party (DUP) stood aside for the Ulster Unionist Party (UUP) in Fermanagh/South Tyrone and Newry/Armagh, the UUP did the same for the UUP in Belfast, East and North.

6 In fact, with the one exception of a rather vague suggestion to establish a women's prison in the Hillsborough agreement, neither the St Andrews Agreement nor the Hillsborough Agreement made any reference to women.

$7 \quad$ For example, out of a sample of 31 major peace processes between 1992 and 2011, only 4 per cent of signatories, 2.4 per cent of chief mediators and 9 per cent of negotiators were women (United Nations Women, 2012:3). And, while there is some evidence to suggest that, since the ratification of resolution 1325 in 2000, peace agreements are more likely to contain specific references to women, they still only account for 16 per cent of all peace agreements (Bell and O'Rourke, 2010).

8 Founded in 1996 to contest the elections to the Northern Ireland Forum -the multiparty talks which led to the Northern Ireland Agreement - the NIWC was a cross-communal and women-only political party established to represent the interests of women in the negotiations.

9 Although there was a notable rise in the number of women elected to the Northern Ireland Assembly after the 2016 elections - 28 per cent, or 30 members out of a total of 108 as compared to 19 per cent in 2011 - the 
11 Following the resignation of Peter Robinson - leader of the DUP and First Minister of the Northern Ireland Assembly - Arlene Foster, albeit the sole candidate in the leadership contest, was elected leader of the DUP in December 2015 and subsequently replaced Peter Robinson as First Minister in January 2016.

12 While part of this notable rise in voting apathy among Protestant males in 2011 could be attributed to an extremely divisive and lack lustre election campaign by unionist politicians, particularly among those from within the UUP (Matthews, 2011), this is not to discount the overall downward trend in turnout within the Protestant/unionist community, a pattern which is now replicated within the Catholic/nationalist population (Russell, 2016).

13 While a breakdown in turnout rates by religion and gender is currently not available for the 2016 Assembly elections, official government figures suggest that the overall rate was 54.91 per cent, as compared to 58.4 per cent during the 2015 Westminster elections.

14 A somewhat different pattern emerges when male members of the two religious communities are considered. Although Catholic males were more supportive of power-sharing than Protestant males, Protestant men were the most supportive of the Assembly/Executive. More specifically, while 72 per cent of Catholic men as compared to 61 per cent of Protestant men endorsed power-sharing, the equivalent figures for support of the Assembly/Executive were 65 per cent and 70 per cent, respectively.

15 The equivalent figures among Protestant and Catholic men were somewhat higher and almost identical at 48 per cent and 50 per cent, respectively.

16 A similar result emerges when the views of Catholic and Protestant men are considered, although the difference in levels of trust between the two 
Protestant women considered the 'issues surrounding Iris Robinson' very important, only 27 per cent of Catholic women endorsed this opinion.

Alternative analysis based on OLS with robust standard errors gave rise to an identical finding. An identical result emerged when the combined effect of religion and communal affiliation, or Catholic-Nationalist women, were used as the distinguishing category for investigation. 


\section{References}

Arostegui, Julie. 2013. 'Gender, Conflict and Peace-Building: How Conflict Can Catalyse Positive Change for Women.' Gender \& Development. 21(3): 533-549.

Baur, Jacqui. 2009. 'Women and the 2005 Election in Liberia.' The Journal of Modern African Studies. 47:2: 193-211.

Bell, Christine and Catherine O' Rourke. 2010. 'Peace Agreement or Pieces of Paper? The Impact of UNSC Resolution 1325 on Peace Process and their Agreements.' International and Comparative Law Quarterly. 59(4): 841-980.

Bjornlund, Eric C. 2004. Beyond Free and Fair: Monitoring Elections and Building Democracy. Baltimore: Johns Hopkins University Press.

Bjornlund, Eric and Cowan Glenn and William Gallery. 2007. 'Election Systems and Political Parties in Post-Conflict and Fragile States.' In Derick W. Brinkerhoff (ed.), Governance in Post-Conflict Societies. London: Routledge, pp. 64-84.

Brancati, Dawn and Jack L. Snyder. 2012. 'Time to Kill: The Impact of Election Timing on Postconflict Stability.' Journal of Conflict Resolution. 57(5): 822853.

Braniff, Maire and Sophie A. Whiting. 2015. 'There's Just no Point Having a Token Women': Gender and Representation in the Democratic Unionist Party in PostAgreement Northern Ireland.' Parliamentary Affairs. 1-22.

Byrne, Siobhan and Allison McCulloch. 2012. Gender, Representation and PowerSharing in Post-Conflict Institutions.' International Peacekeeping. 19(5): 565580 .

Campbell, Rosie. 2012. 'What Do We Really Know About Women Voters? Gender, Elections and Public Opinion.' The Political Quarterly. 83(4): 703-710.

Carroll, Susan J. 2014. 'Voting Choices: How and Why the Gender Gap Matters.' In Susan J. Carroll and Richard L. Fox (eds.), Gender and Elections: Shaping the Future of American Politics. pp. 119-145.

Coffe, Hilde and Catherine Bolzendahl. 2011. 'Gender Gaps in Political Participation Across Sub-Saharan African Nations.' Social Indicators Research. 102: 245264.

Fearon, Kate. 1999. Women's Work: The Story of the Northern Ireland Women's Coalition. Belfast: Blackstaff Press.

Flores, Thomas Edward and Irfan Nooruddin. 2012. 'The Effect of Elections on Postconflict Peace and Reconciliation.' The Journal of Politics. 74:2: 558-570.

Fornos, Caroline A., Power, Timothy J. and James C. Garand. 2004. 'Explaining Voter Turnout in Latin America, 1980 to 2000.' Comparative Political Studies. 37:8: 909-940.

Galligan, Yvonne. 2006. "Women in Northern Ireland's Politics: Feminising an "Armed Patriarchy." In Marian Sawer, Manon Tremblay and Linda Trimble (eds.), Representing Women in Parliament: A Comparative Study. Oxon: Routledge, pp. 204-220. 
Galligan, Yvonne. 2013. 'Gender and Politics in Northern Ireland: The Representation Gap Revisited.' Irish Political Studies. 28(3): 413-433.

Gormley-Heenan, Cathy and Paula Devine. 2010. 'The "Us" in Trust: Who Trusts Northern Ireland's Political Institutions and Actors? ' Government and Opposition. 45(2): 143-165.

Harbom, Lotta, Hogbladh, Stina and Peter Wallensteen. 2006. 'Armed Conflict and Peace Agreements.' Journal of Peace Research. 43:5: 617-631.

Hassenstab, Christine M. and Sabrina P. Ramet. (eds.) 2015. Gender (in)equality and Gender Politics in Southeastern Europe. Basingstoke: Palgrave Macmillan.

Hayes, Bernadette C. and Ian McAllister. 2012. 'Gender and Consociational PowerSharing in Northern Ireland.' International Political Science Review. 34(2): 123-139.

Hayes, Bernadette C. and Ian McAllister. 2013. Conflict to Peace: Politics and Society in Northern Ireland Over Half a Century. Manchester: Manchester University Press.

Hoddie, Matthew and Caroline A. Hartzell. 2005. 'Power Sharing in Peace Settlements: Initiating the Transition from Civil War.' In Philip G. Roeder and Donald Rothchild (ed.), Sustainable Peace: Power and Democracy After Civil Wars. Ithacha: Cornell University Press, pp. 83-106.

Hoddie, Matthew and Caroline A. Hartzell. 2010. 'Introduction.' In Matthew and Caroline A. Hartzell (ed.), Strengthening Peace in Post-Civil War States. Chicago: University of Chicago Press, pp. 1-25.

Hoewer, Melanie. 2013. 'UN Resolution 1325 in Ireland: Limitations and Opportunities of the International Framework on Women, Peace and Security.' Irish Political Studies. 28(3): 450-468.

Horgan, Goretti and Julia S. O'Connor. 2014. 'Abortion and Citizenship Rights in a Devolved Region of the UK.' Social Policy and Society. 13(1): 39-49.

Huddy, Leonie, Cassese, Erin and Mary-Kate Lizotte. 2008. 'Sources of Political Unity and Disunity Among Women.' In Lois Duke Whitaker (ed.), Voting the Gender Gap. Chicago: University of Illinois Press, pp. 141-169.

Inglehart, Ronald and Pippa Norris. 2003. Rising Tide: Gender Equality and Cultural Change Around the World. Cambridge: Cambridge University Press.

Jarman, Neil. 2004. 'From War to Peace? Changing Patterns of Violence in Northern Ireland, 1990-2003.' Terrorism and Political Violence. 16(3): 420-438.

Kelley, Judith G. 2012. Monitoring Democracy. Princeton: Princeton University Press.

Kennedy, Ronan, Pierson, Claire and Jennifer Thomson. 2016. 'Challenging Identity Hierarchies: Gender and Consociational Power-Sharing.' British Journal of Politics and International Relations. DOI: 10.1177/1369148116647334.

Kostadinova, Tatiana and Timothy J. Power. 2007. 'Does Democratization Depress Participation? Voter Turnout in the Latin American and Eastern European Transitional Democracies.' Political Research Quarterly. 60(3): 363-377. 
Lindberg, Staffan I. 2006. Democracy and Elections in Africa. Johns Hopkins University Press.

Lyons, Terrence. 2005. Demilitarizing Politics: Elections on the Uncertain Road to Peace. Lynne Rienner.

MacManus, Susan A. 2014. 'Voter Participation and Turnout: The Political Generational Divide Among Women Voters.' In Susan J. Carroll and Richard L. Fox (eds.), Gender and Elections: Shaping the Future of American Politics. pp. 80-118.

Mansfield, Edward D. and Jack Snyder. 2005. Electing to Fight: Why Emerging Democracies Go to War. Cambridge: MIT Press.

Manuel, Tiffany. 2006. 'Envisioning the Possibilities for a Good Life: Exploring the Public Policy Implications of Intersectionality Theory.' In Carol Hardy-Fanta (ed.), Intersectionality and Politics: Recent Research on Gender, Race and Political Representation in the United States. New York: Haworth Press, pp. 173-203.

Matthews, Neil. 2011. 'The Northern Ireland Assembly Election 2011.' Irish Political Studies. 27(2): 341-358.

Matthews, Neil. 2014. 'Gendered Candidate Selection and the Representation of Women in Northern Ireland.’ Parliamentary Affairs. 67: 617-646.

McGarry, John and Brendan O'Leary. 2009. 'Power Shared After the Deaths of Thousands.' In Rupert Taylor (ed.), Consociational Theory: McGarry and O'Leary and the Northern Ireland Conflict. Abingdon: Routledge, pp. 15-84.

McKittrick, David. 2010. 'Stormont's First Minister Peter Robinson Unseated ASfter Year of Scandal.' Independent. Friday 7th May. http://www.independent.co.uk/news/uk/politics/stormonts-first-minister-peterrobinson-unseated-after-year-of-scandal-1965819.html

O’Donnell, Guillermo Philippe C. Schmitter. 2013. Transitions from Authoritarian Rule: Tentative Conclusions About Uncertain Democracies. Baltimore: Johns Hopkins University Press, New Edition.

Paris, Roland. 2004. At War's End: Building Peace After Civil Conflict. Cambridge: Cambridge University Press.

Potter, Michael. 2013. Women in the Northern Ireland Assembly. Northern Ireland Assembly: Research and Information Service Research Paper.

Reilly, Benjamin. 2008. 'Post-War Elections: Uncertain Turning Points of Transition.' In Anna K. Jarstad and Timothy D. Sisk (eds.), From War to Democracy: Dilemmas of Peacebuilding. Cambridge: Cambridge University Press, pp. 157181.

Russell, Raymond. 2016. Election Report: Northern Ireland Assembly Election, 5 May 2016. Northern Ireland Assembly: Research and Information Service Research Paper. 
Tonge, Jonathan and Jocelyn Evans. 'Another Communal Headcount: The Election in Northern Ireland.' In Andrew Geddes and Jonathan Tonge (ed.), Britain Votes 2015. Oxford: Oxford University Press, pp. 117-132.

Tripp, Aili Mari. 2015. Women and Power in Postconflict Africa. Cambridge: Cambridge University Press.

United Nations Women. 2012. Women's Participation in Peace Negotiations:

Connections Between Presence and Influence. Available at:

http://www.unwomen.org/ /media/headquarters/attachments/sections/library/pu blications/2012/10/wpssourcebook-03a-womenpeacenegotiations-en.pdf

Waylen, Georgina. 2007. Engendering Transitions: Women's Mobilization, Institutions and Gender Outcomes. Oxford: Oxford University Press. 
Table 1: Religious Differences in Electoral Turnout Among Women

\begin{tabular}{lccc}
\hline & Catholic & $\begin{array}{c}\text { (Percentages) } \\
\text { Protestant }\end{array}$ & All \\
\hline & & & \\
Yes & 70.4 & 55.4 & 61.8 \\
No & 29.6 & 44.6 & 38.2 \\
$(\mathrm{~N})$ & $(324)$ & $(437)$ & $(761)$ \\
\hline
\end{tabular}

Question: Did you manage to vote in the 2015 General (Westminster) election that was held recently.

Source: Northern Ireland General Election Survey, 2015. 
Table 2: The Religious Gap in Electoral Turnout, 1992-2015

\begin{tabular}{lccccc}
\hline & 1992 & 1998 & 2003 & 2011 & 2015 \\
\hline Women & -7 & +8 & +7 & +8 & +15 \\
Men & -5 & -7 & -5 & +12 & +3 \\
All & -7 & +1 & +3 & +10 & +10 \\
\hline
\end{tabular}

Note: The religious gap is the percentage of Catholics minus the percentage of Protestants who voted.

Sources: 1992, 1998, 2003, 2011 and 2015 Northern Ireland Election Surveys. 
Table 3: The Religious Differences in Support for Devolution Among Women

\begin{tabular}{lccc}
\hline & Catholic & $\begin{array}{c}\text { (Percentages) } \\
\text { Protestant }\end{array}$ & All \\
\hline Northern Ireland Assembly: & & & \\
Support & 70.0 & 68.3 & 69.0 \\
Neither & 22.7 & 28.3 & 25.9 \\
Oppose & 7.3 & 3.4 & 5.0 \\
(N) & $(330)$ & $(445)$ & $(775)$ \\
Power-Sharing: & & & \\
Support & 77.3 & 59.1 & 66.9 \\
Neither & 17.3 & 34.3 & 27.0 \\
Oppose & 5.5 & 6.5 & 6.1 \\
(N) & $(330)$ & $(443)$ & $(773)$ \\
\hline
\end{tabular}

Questions: And in terms of the current political arrangements, can you please tell me how you feel about the following: The Northern Ireland Assembly and Executive; The requirement that Unionists and Nationalists share power.

Source: Northern Ireland General Election Survey, 2015. 
Table 4: The Religious Gap in Support for Devolution Among Women, 1998-2015

\begin{tabular}{lcccc}
\hline & 1998 & 2003 & 2010 & 2015 \\
\hline NI Assembly \& Executive & +7 & +11 & +2 & +2 \\
Power-Sharing & +27 & +24 & +11 & +18 \\
\hline
\end{tabular}

Note: The religious gap is the percentage of Catholic women minus the percentage of Protestant women who expressed 'strong support' or 'support'.

Sources: 1998, 2003, 2010 and 2015 Northern Ireland Election Surveys. 
Table 5: The Religious Differences in Support for Political Parties and Trust in Leaders Among Women

\begin{tabular}{lccc}
\hline & Catholic & $\begin{array}{c}\text { (Percentages) } \\
\text { Protestant }\end{array}$ & All \\
\hline & & & \\
Partisanship: & & & \\
Yes & 45.9 & 40.3 & 42.8 \\
No & 54.1 & 59.7 & 57.2 \\
{$[\mathrm{~N}]$} & {$[320]$} & {$[419]$} & {$[739]$} \\
& & & \\
Trust in Leaders: & & & \\
Peter Robinson/Martin McGuinness & 64.4 & 49.2 & 55.7 \\
(Peter Robinson) & $(22.0)$ & $(48.2)$ & $(36.9)$ \\
(Martin McGuinness) & $(62.8)$ & $(7.0)$ & $(31.1)$ \\
{$[\mathrm{N}]$} & {$[323]$} & {$[427]$} & {$[750]$} \\
\hline
\end{tabular}

Questions: Generally speaking do you think of yourself as a supporter of any political party? Do you think of yourself as closer to one party in Northern Ireland than to others? ; On a scale of $0-10$, where 0 means complete distrust in a leader and 10 means complete trust, please rate these leaders.

Note: Trust in leaders is scored over 6 on the $0-10$ scale.

Source: Northern Ireland General Election Survey, 2015 
Table 6: Changing Levels of Trust in Political Leaders Among Women

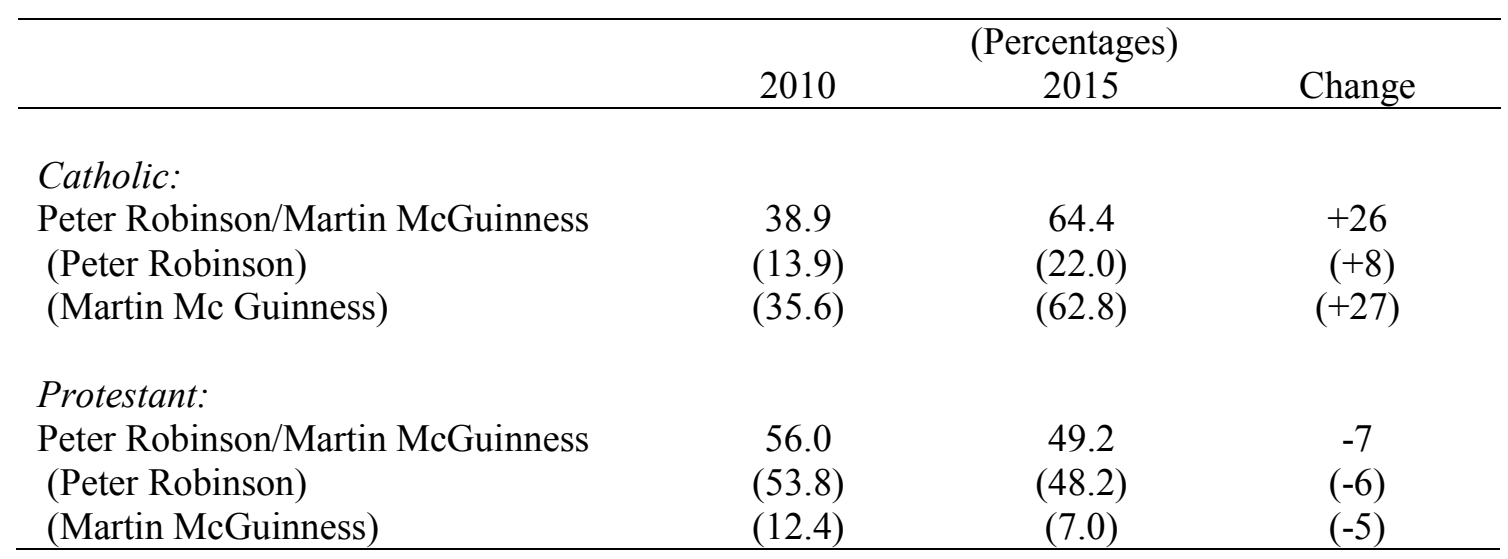

Sources: 2010 and 2015 Northern Ireland Election Surveys. 
Table 7: Explaining the Religion Gap in Electoral Turnout Among Women $(n=633)$

\begin{tabular}{|c|c|c|c|c|c|c|c|c|c|c|c|c|}
\hline & \multicolumn{3}{|c|}{ Model 1} & \multicolumn{3}{|c|}{ Model 2} & \multicolumn{3}{|c|}{ Model 3} & \multicolumn{3}{|c|}{ Model 4} \\
\hline & & & Odds & & & Odds & & & Odds & & & Odds \\
\hline & Est & $(\mathrm{SE})$ & Ratio & Est & $(\mathrm{SE})$ & Ratio & Est & $(\mathrm{SE})$ & Ratio & Est & $(\mathrm{SE})$ & Ratio \\
\hline \multicolumn{13}{|l|}{ Control variables: } \\
\hline Marital status (single) & --- & --- & --- & -0.29 & $(0.23)$ & 0.75 & -0.24 & $(0.24)$ & 0.78 & -0.38 & $(0.29)$ & 0.69 \\
\hline Church attendance (attends) & --- & --- & --- & $0.62 *$ & $(0.31)$ & 1.86 & 0.52 & $(0.33)$ & 1.68 & 0.04 & $(0.37)$ & 1.02 \\
\hline Age (years) & --- & --- & --- & $0.02 *$ & $(0.01)$ & 1.02 & $0.02 *$ & $(0.01)$ & 1.02 & 0.01 & $(0.01)$ & 1.01 \\
\hline \multicolumn{13}{|l|}{ Education: } \\
\hline Tertiary & --- & --- & --- & $0.75 *$ & $(0.33)$ & 2.11 & $0.73 *$ & $(0.34)$ & 2.07 & 0.70 & $(0.39)$ & 2.01 \\
\hline Secondary & --- & --- & --- & 0.39 & $(0.26)$ & 1.48 & 0.34 & $(0.27)$ & 1.41 & 0.34 & $(0.32)$ & 1.41 \\
\hline No qualification ${ }^{\mathrm{a}}$ & --- & --- & --- & & & & & & & & & \\
\hline Employment (labour active) & --- & --- & --- & -0.23 & $(0.19)$ & 0.79 & -0.22 & $(0.19)$ & 0.80 & -0.30 & $(0.23)$ & 0.75 \\
\hline Identity (British) & & & & 0.18 & $(0.27)$ & 1.20 & 0.08 & $(0.28)$ & 1.08 & -0.19 & $(0.32)$ & 0.83 \\
\hline \multicolumn{13}{|l|}{ Political Institutions: } \\
\hline Assembly (support) & --- & --- & --- & --- & --- & --- & $2.98 * *$ & $(0.55)$ & 19.75 & $2.08 * *$ & $(0.63)$ & 7.98 \\
\hline Power-sharing (support) & --- & --- & --- & --- & --- & --- & -0.23 & $(0.52)$ & 0.79 & -0.22 & $(0.62)$ & 0.80 \\
\hline \multicolumn{13}{|c|}{ Party Support and Trust in Political Leaders: } \\
\hline Partisanship (yes) & --- & --- & --- & --- & --- & --- & --- & --- & --- & $2.02 * *$ & $(0.24)$ & 7.54 \\
\hline Robinson/McGuinness & --- & --- & --- & --- & --- & --- & --- & --- & --- & $1.38 * *$ & $(0.21)$ & 3.98 \\
\hline \multicolumn{13}{|l|}{ Religion Effect: } \\
\hline Catholic & $0.66 * *$ & $(0.17)$ & 1.94 & $0.79 * *$ & $(0.28)$ & 2.20 & $0.85 * *$ & $(0.28)$ & 2.35 & 0.47 & $(0.32)$ & 1.60 \\
\hline Constant & $0.25 *$ & & & $-1.06 *$ & & & $-2.91 * *$ & & & $-2.90 * *$ & & \\
\hline Nagelkerke R-Square & .033 & & & .091 & & & .179 & & & .452 & & \\
\hline
\end{tabular}

Note: The dependent variable is coded 0 (not vote) and 1 (vote); Standard errors are in parentheses; ${ }^{\text {a }}$, omitted category of comparison, *, statistically significant at $\mathrm{p}<.05, * *, \mathrm{p}<.01$.

Source: Northern Ireland Election Survey, 2015. 
